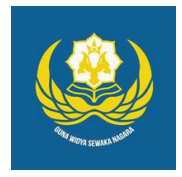

Jurnal Analogi Hukum

Journal Homepage: https://ejournal.warmadewa.ac.id/index.php/analogihukum

\title{
Peran Mediasi dalam Penyelesaian Sengketa Sertipikat Gandadi Badan Pertanahan Nasional (BPN) Kabupaten Klungkung
}

\author{
I Gede Agus Marta Dinata*, Anak Agung Sagung Laksmi Dewi dan Luh Putu Suryani \\ Universitas Warmadewa, Denpasar-Bali, Indonesia \\ *gusmarta222@gmail.com
}

How To Cite:

Dinata, I, G, A, M., Dewi, A, A, S, L., Suryani, L, P. (2021). Peran Mediasi dalam Penyelesaian Sengketa Sertipikat Gandadi Badan Pertanahan Nasional (BPN) Kabupaten Klungkung. Jurnal Analogi Hukum. 3 (2). 152-155. Doi: https://doi.org/10.22225/ah.3.2.2021.152-155

\begin{abstract}
Land or territory is the main element of a country. The magnitude of the influence of land on human life, makes the State obliged to guarantee legal certainty for the land rights even though these rights are still limited by the interests of other people, society, and the state. From the background, problems can be formulated such as 1). How is the dual certificate dispute resolution through mediation at the Klungkung Regency National Land Agency (BPN)? 2). What are the obstacles in resolving a double certificate dispute at the National Land Agency (BPN) Klungkung Regency? This research is empirical legal research by describing the law as law in action. The state policy on land tenure security was strengthened and its rights and obligations were regulated in the Basic Agrarian Law (UUPA) issued in 1960. Nevertheless, land issues cannot be spared from people's lives. One of the problems that often occurs is the existence of multiple certificates. In this case, the National Land Agency has an important role to play in resolving it.
\end{abstract}

Keywords: Land; double certificate; mediation

\begin{abstract}
Abstrak - Tanah atau wilayah merupakan unsur utama dari suatu negara. Besarnya pengaruh tanah terhadap kehidupan manusia, menjadikan Negara berkewajiban untuk memberikan jaminan kepastian hukum terhadap hak atas tanah itu walaupun hak tersebut tetap dibatasi oleh kepentingan orang lain, masyarakat, dan terlebih lagi negara. Dari latar belakang dapat dirumuskan permasalah seperti 1). Bagaimanakah penyelesaian sengketa sertipikat ganda melalui mediasi di Badan Pertanahan Nasional (BPN) Kabupaten Klungkung? 2). Bagaimanakah hambatan-hambatan dalam menyelesaikan sengketa sertipikat ganda di Badan Pertanahan Nasional (BPN) Kabupaten Klungkung? Penelitian ini adalah penelitian hukum empiris dengan melakukan mendeskripsikan hukum sebagai law in action. Kebijakan negara atas kepastian jaminan kepemilikan tanah itu diperkuat dan diatur hak dan kewajibannya dalam Undang Undang Pokok Agraria (UUPA) yang diterbitkan pada tahun 1960. Meskipun demikian, permasalah tanah tidak dapat luput dari kehidupan masyarakat. salah satu permasalah yang sering terjadi yakni adanya sertipikat ganda. Dalam hal ini Badan Pertanahan Nasional memiliki peran penting untuk dapat menyelesaikannya.
\end{abstract}

Kata Kunci: tanah; sertipikat ganda; mediasi

\section{Pendahuluan}

Tanah merupakan kebutuhan dasar dalam pelaksanaan kegiatan produktif manusia, baik sebagai wadahnya maupun sebagai faktor produksi. Menurut Pasal 4 ayat (1) UUPA tanah adalah permukaan bumi yang dapat diberikan kepada dan dipunyai oleh orang-orang baik sendiri maupun bersama-sama dengan orang lain serta badan hukum . Dengan konsep Negara Kesatuan Republik Indonesia yaitu negara hukum yang berorientasi kepada kesejahteraan umum sebagaimana yang tersurat didalam Undang-undang Dasar Republik Indonesia Tahun 1945, maka tidak akan terlepas dari sengketa hukum atas tanah yang merupakan permasalahan mendasar dalam masyarakat khususnya menyangkut tanah. 
Bagi Bangsa Indonesia yang merupakan suatu negara yang disebut sebagai bangsa agraris ataupun kepulauan, tanah mempunyai kedudukan yang sangat penting dalam rangka penyelenggaraan hidup dan kehidupan manusia. Tanah merupakan kebutuhan dasar dalam pelaksanaan kegiatan produktif manusia, baik sebagai wadahnya maupun sebagai faktor produksi.(Dr. J. Andi Hartanto, 2014 9)

Hak atas tanah merupakan hak dasar yang sangat berarti bagi masyarakat untuk harkat dan kebebasan diri seseorang. Oleh karena itu, kepemilikan atas tanah adalah merupakan kebutuhan pokok dalam kehidupan manusia, baik sebagai tempat tinggal, kebutuhan lain maupun sebagai sumber penghasilan untuk memenuhi kebutuhan-kebutuhan hidup.( Boedi Harsono, 2007 22) Hukum Tanah Nasional yang ketentuan pokoknya ada di dalam Undang- undang Pokok Agraria merupakan dasar dan landasan hukum untuk memiliki dan menguasai tanah oleh orang dan badan hukum baik untuk hunian, untuk pertanian maupun dalam rangka memenuhi keperluannya.

Dalam pelaksanaannya walaupun pendaftaran tanah sudah dilakukan, namun masih terjadinya sengketa-sengketa hak-hak atas tanah di tengah-tengah masyarakat yang bahkan sampai pada gugatan-gugatan ke Pengadilan. sertipikat ganda merupakan salah satu permasalahan yang ditemukan dalam masyarakat. sertipikat ganda atas tanah secara singkat dapat diartikan sebagai sertipikat- sertipikat yang menguraikan satu bidang tanah yang sama atau secara luas sertipikat ganda adalah surat keterangan kepemilikan (dokumen) dobel yang diterbitkan oleh badan hukum yang mengakibatkan adanya pendudukan hak yang saling bertindihan antara satu bagian dengan bagian lain, sehingga terbitlah sertipikat ganda yang berdampak pada pendudukan tanah secara keseluruhan maupun sebagian tanah milik orang lain. Tingginya masalah pertanahan tidak hanya meresahkan masyarakat tetapi juga sangat mempengaruhi kinerja BPN sebagai institusi yang mempunyai tugas pokok melaksanakan administrasi pertanahan. Setiap sengketa tanah memerlukan penyelesaian, baik dengan cara litigasi maupun non-litigasi dan BPN memiliki peranan yang penting dalam hal ini.

Berdasarkan pada uraian di atas, maka dapat ditemukan rumusan masalah sebagai berikut; Bagaimanakah penyelesaian sengketa sertipikat ganda melalui mediasi di Badan Pertanahan Nasional (BPN) Kabupaten Klungkung?; Bagaimanakah hambatanhambatan dalam menyelesaikan sengketa sertipikat ganda di Badan Pertanahan Nasional
(BPN) Kabupaten Klungkung?

\section{Metode}

Dalam penelitian digunakan pendekatan empiris. Dalam pendekatan empiris, hukum sebagai law in action, dideskripsikan sebagai gejala sosial yang empiris dengan demikian hukum tidak sekedar diberikan arti sebagai jalinan nilai- nilai, keputusan pejabat, jalinan kaidah dan norma, hukum positif tertulis, tetapi juga dapat diberikan makna sebagai sistem ajaran tentang kenyataan, perilaku yang teratur dan ajeg.

\section{Hasil Penelitian Dan Pembahasan}

\section{Penyelesaian sengketa sertipikat ganda me- lalui mediasi di Badan Pertanahan Nasional (BPN) Kabupaten Klungkung}

Sertipikat ganda adalah kejadian sebidang tanah memiliki 2 sertipikat tanah yang dimiliki oleh 2 orang yang berbeda.( Ali Achmad Chomzah, 2002 139). sertipikat ganda atas tanah adalah sertipikat yang diterbitkan oleh BPN yang akibat adanya kesalahan pendataan pada saat melakukan pengukuran dan pemetaan pada tanah, sehingga terbitlah sertipikat ganda yang berdampak pada pendudukan tanah secara keseluruhan ataupun sebagaimana tanah milik orang lain. Apabila ditinjau dari pengertian sertipikat itu sendiri maka sertipikat adalah tanda bukti hak atas tanah, yang dikeluarkan oleh pemerintah dalam rangka penyelenggaraan pendaftaran tanah menurut ketentuan peraturan dan perundang-undangan.( Ali Ahmad Chomzah, 2007 57)

Sertipikat ganda adalah surat bukti kepemilikian hak atas tanah yang diterbitkan lembaga hukum (BPN) yang terdiri diatas satu objek hak yang bertindih antara satu objek tanah sebagian atau keseluruhan, yang dapat terjadi suatu akibat hukum. Pensertipikatan tanah tampaknya masih cenderung kepada akses permintaan, yang jauh melampaui sisi penawaran, meskipun proyek-proyek administrasi pertanahan seperti prona dan proyek ajudikasi relatif berhasil mencapai tujuannya. Jika dicermati, konflik pertanahan yang terjadi selama ini berdimensi luas, baik konflik horizontal maupun konflik vertikal. Badan Pertanahan Nasional (BPN) merupakan lembaga pemerintahan yang bertugas untuk melaksanakan dan mengembangkan administrasi pertanahan. Dalam melaksanakan tugas tersebut, penyelesaian masalah pertanahan merupakan salah satu fungsi yang menjadi kewenangan BPN. Penyelesaian sengketa tanah melalui mediasi 
oleh BPN perlu dilandasi dengan kewenangankewenangan yang sah berdasarkan peraturan perundang-undangan.

Cara penyelesaian sengketa mediation merupakan cara yang paling utama disarankan oleh pihak BPN, yang mana melalui lembaga mediasi, para pihak dapat mengemukakan kehendaknya dan akan dipertemukan guna mencari penyelesaian yang terbaik melalui negosiasi-negosiasi sehingga menghasilkan kesepakatan penyelesaian sengketa yang dapat diterima oleh kedua belah pihak, dan tidak kalah pentingnya adalah biaya yang harus dikeluarkan oleh para pihak dalam menyelesaikan sengketanya. Apabila didalam penyelesaian sengketa para pihak yang bersengketa tidak sepakat dengan diadakannya penyelesaian melalui lembaga mediasi, maka pihak yang bersengketa dapat menyelesaikan permasalahannya melalui lembaga lain seperti lembaga litigasi atau lembaga peradilan.

Masalah pertanahan telah muncul dalam banyak aspek dengan beragam wujud. Berbagai upaya penyelesaian telah ditawarkan baik melalui musyawarah atau mediasi tradisional maupun mediasi pertanahan yang dibentuk dalam lingkungan Instansi Badan Pertanahan Nasional. Penyelesaian cara mediasi tidak selamanya memberikan penyelesaian yang memuaskan dan memberi penyelesaian yang tuntas, sementara perkara yang masuk ke Pengadilan sudah kian menumpuk, sehingga perlu dipikirkan untuk membentuk Pengadilan Pertanahan yang dapat memberikan penyelesaian kasus-kasus pertanahan secara cepat dan sesuai dengan prinsip keadilan.

\section{Hambatan-Hambatan dalam Menyelesaikan Sengketa Sertipikat Ganda di Badan Per- tanahan Nasional (BPN) Kabupaten Klungkung}

Dalam Peraturan Pemerintah Republik Indonesia Nomor 24 Tahun 1997 tentang Pendaftaran Tanah pada Pasal 1 Nomor 20 disebutkan bahwa sertipikat adalah surat tanda bukti hak sebagaimana dimaksud dalam Pasal 19 ayat (2) huruf c UUPA untuk hak atas tanah, hak pengelolaan, tanah wakaf, hak milik atas satuan rumah susun dan hak tanggungan yang masingmasing sudah dibukukan dalam buku tanah yang bersangkutan. Selanjutnya, dalam Peraturan Menteri Negara Agraria/Kepala BPN No. 9 Tahun 1999 tentang Tata Cara Pemberian Dan Pembatalan Hak atas Tanah

Negara dan Hak Pengelolaan pada Pasal 3 ayat (1) disebutkan bahwa
Pemberian dan pembatalan Hak Milik, Hak Guna Usaha, Hak Guna

Bangunan, Hak Pakai dan Hak Pengelolaan dilakukan oleh Menteri. Pemberian dan pembatalan hak sebagaimana dimaksud pada ayat (1), menteri dapat melimpahkan kewenangannya kepada Kepala Kantor Wilayah, Kepala Kantor Pertanahan dan Pejabat yang ditunjuk. Sertipikat tanah menurut ketentuan di atas merupakan tindakan pemerintah yang memberikan akibat hukum, berupa pemberian hak atas tanah, serta dikeluarkan oleh pejabat TUN. Dengan demikian, sertifkat tanah merupakan keputusan TUN yang merupakan obyek sengketa

Peradilan TUN. Hal ini dikarenakan dalam Undang-undang No. 5 Tahun 1985 tentang Peradilan Tata Usaha Negara pada Pasal 1 Nomor 3 disebutkan bahwa Keputusan Tata Usaha Negara adalah suatu penetapan tertulis yang dikeluarkan oleh Badan atau Pejabat Tata Usaha Negara yang berisi tindakan hukum Tata Usaha Negara yang berdasarkan peraturan perundang-undangan yang berlaku, yang bersifat konkret, individual, dan final, yang menimbulkan akibat hukum bagi seseorang atau badan hukum perdata .

Tanah merupakan hal yang sangat penting dalam kehidupan masyarakat di Indonesia. Kurangnya transparansi dalam hal penguasaan dan pemilikan tanah disebabkan oleh terbatasnya data dan informasi penguasaan dan pemilikan tanah, serta kurang transparannya informasi yang tersedia di masyarakat merupakan salah satu penyebab timbulnya sengketa-sengketa tanah. Untuk mendapatkan jaminan kepastian hukum atas bidang tanah, memerlukan perangkat hukum yang tertulis, lengkap, jelas dan dilaksanakan secara konsisten isi ketentuan -ketentuan yang berlaku.

Masalah sengketa tanah sering kali membuat masyarakat dirugikan oleh suatu penetapan oleh pejabat yang berwenang dalam hal ini Kepala Kantor BPN, oleh karena itu institusi berusaha untuk menyelesaikan sengketasengketa tanah yang ada di BPN Kabupaten Klungkung, namun dalam pelaksanaannya seringkali mengalami kendala-kendala. Berdasarkan wawancara dengan Bapak Gede Irwan Agustian, S.ST., MH Selaku Kepala Seksi Hubungan Hukum Pertanahan Kabupaten Klungkung, terdapat beberapa kendala yang selalu dialami pihak BPN Kabupaten Klungkung yakni

Kebanyakan kasus sertipikat ganda di BPN Kabupaten Klungkung diselesaikan lewat jalur 
pengadilan.

Jika terjadi overlapping harus ada salah satu sertipikat yang dicabut/dibatalkan, dan pihak BPN Kabupaten Klungkung baru dapat mencabut dan membatalkan apabila telah mendapatkan putusan dari PTUN.

Hal tersebutlah yang menjadi kendala dalam menyelesaikan sengketa sertipikat hak milik ganda di BPN Kabupaten Klungkung, yang mana permasalahan tersebut tidak dapat ditempuh dengan jalur mediasi, sehingga hal tersebut juga menyulitkan pihak BPN Kabupaten Klungkung serta banyak membuang waktu kedua belah pihak yang berperkara belum lagi pihak-pihak tersebut tetap merasa dirugikan satu sama lainnya karena sama-sama merasa memiliki objek dari tanah tersebut. Selain itu banyaknya kasus-kasus sertipikat ganda yang ada di Kabupaten Klungkung yang sampai saat ini sangat sulit diatasi oleh Badan Pertanahan Nasional Kabupaten Klungkung.

\section{Simpulan}

Berdasarkan uraian yang telah di paparkan dalam pembahasan sebelumnya, maka penulis dapat menarik simpulan sebagai berikut. Penyelesaian sertipikat Hak Mili Ganda (overlapping) melalui jalur mediasi di kantor Badan Pertanahan Nasional di Kabupaten Klungkung yakni diawali dengan pengaduan kepada Kantor BPN Kabupaten Klungkung perihal objek tanah yang bersengketa, selanjutnya dilakukan pemanggilan para pihak yang bersengketa untuk mediasi, pada saat mediasi dilakukan, BPN telah menyiapkan tim mediator yang telah ditunjuk berdasarkan Surat Keputusan yang mana orang-orang ini sebagai penengah yang membantu menyelesaikan permasalahan kedua belah pihak yang bersengketa.

Kebanyakan kasus sertipikat ganda di BPN Kabupaten Klungkung diselesaikan lewat jalur pengadilan, karena menurut mereka apabila sengketa seperti ini diselesaikan lewat pengadilan rasanya lebih adil dan tidak dapat diganggu gugat putusan dari hakim tersebut, sehingga dari hal ini sangat menyulitkan pihak BPN Kabupaten Klungkung mengingat pihak BPN juga selalu mengutamakan jalur mediasi untuk mendapatkan keputusan yang mufakat namun kedua belah pihak yang bersengketa biasanya tidak mau dan lebih mempercayakan pada hakim dalam pengadilan.

\section{Daftar Pustaka}

Chomzah, A, A. (2007). Sertipikat dan Permasalahannya dan Seri Hukum Pertanahan. Jakarta: Prestasi Pustaka
Publisher.

Chomzah, A, A. (2002). Hukum Pertanahan Pemberian Hak Atas Tanah Negara, Sertipikat dan Permasalahan. Jakarta: Prestasi Pustaka.

Chomzah, A, A. (2002). Hukum Pertanahan. Jakarta: Prestasi Pustaka.

Harsono, B. (2007). Hukum Agraria Indonesia (Sejarah Pembentukan Undang-Undang Pokok Agraria, Isi dan Pelaksanaannya), Jilid 1, Edisi Revisi. Jakarta: Djambatan,

Hartanto, A. (2014). Hukum Pertanahan Karakteristik Jual Beli Tanah Yang Belum Terdaftar Hak Atas Tanahnya. Surabaya: Laksbang Justitia. 